\title{
THE EFFECT OF EXPIRED BREAD MEALAS CORN SUBSTITUTION IN DIET ON BROILER PERFORMANCE
}

\author{
S. Kismiati, W. Sarengat, U. Atmomarsono, R. Salaamun and M. F. Alvi \\ Faculty of Animal Agriculture, Diponegoro University, \\ Tembalang Campus, Semarang 50275 - Indonesia \\ Corresponding E-mail : kismiati59@gmail.com
}

Received January 13, 2010; Accepted May 12, 2010

\begin{abstract}
An experiment was conducted to investigate the expired bread meal used as corn substitution in the broiler diets to optimally the product performance. One hundred day old chick (DOC) male broilers were given the same diet until 2 weeks old, and then given the treatment diet until 7 weeks of age. A Completely Randomized Design was used in this study. Data were analyzed by variance of analysis, and followed by Duncan's Multiple Range Test The treatments were : T0 $=$ control feed (without expired bread meal), $\mathrm{T} 1=$ corn substituted with $10 \%$ expired bread meal, $\mathrm{T} 2=$ corn substituted with $20 \%$ expired bread meal, $\mathrm{T} 3=$ corn substituted with $30 \%$ expired bread meal and $\mathrm{T} 4=$ corn substituted with $40 \%$ expired bread meal. The result indicated that corn substituted with expired bread meal up to $40 \%$ has not significantly affected on carcass weight, carcass percentage and feed conversion, but decreased significantly on feed consumption and body weight gain. It can be concluded that the use of expired bread meal 30\% of the proportion of corn produced the most optimal broiler performance. The substitution corn with expired bread meal $40 \%$ was decreased body weight gain.
\end{abstract}

Keywords: carcass, corn, expired bread, feed consumption, weight gain

\section{INTRODUCTION}

Broiler chickens are the most potential source of animal protein because of the rapidity of their growth. Broiler usually is reared for about 4 to 7 weeks. Almost all of feed stuff for poultry are still imported, such as corn, fish meal, poultry meat meal and extracted soybean. NRC (1994) recommended that proportion of corn for poultry feed was about $70 \%$. In most poultry diets, corn will be the major contributor of metabolizable energy (Leeson and Summers, 2005). The energy was verry importen for maintenanced, growth and production. The most metabolism process needed energy from the feed (Labier and Leclercq, 1994).

Indonesian feed meal has still imported corn to fulfill the requirement, therefore using corn in poultry ration will increase the price. In addition, corn was also used as fuel (methanol); therefore the use of corn will compete with foreign exchange resources. Such conditions, it would be a threaten to the poultry industry facilities, especially feed meal production.

Expired bread is waste product of selling bread that is not marketable and not for human consumption. Bread is produced by large companies as well as home industry. In large companies (bakery), expired bread is processed into dried product bread, but at home industry, expired bread is useless and not profitable product. Generally, bread consisted of wheat flour, eggs, sugar, margarine, cooking oil, and some materials used as the contents of bread are green bean, coconut, chicken meat, beef meat etc. Wheat flour is a source of energy for poultry. Eggs, beans and meat contain high protein and rich in essential amino acids.

Bread and its waste products contain various vitamins and minerals (NRC, 1994). However, the expired bread has bad flavour/taste, damage nutrients, containing fungi and toxins (poisons). Poultry is very sensitive to mycotoxin. There are several species of fungi that produce toxin, such as Aspergillus sp, mycotoxins, Penicilium $s p$ and Fusarium sp. (Lesson and Summers, 2005). Mycotoxins lead high mortality (Ensminger, 1980 and Afzal and Zahid, 2004). Chowdhury and Smith (2004) state that mycotoxins contamination decreased feed consumtion in the first 4 weeks of laying hens. Feed comsumtion increased, 
however, from 4 to 12 weeks. Swammy et al. (2004) reported that mycotoxins affected significantly the decreasing of broiler weight gain from 21 to 42 weeks of age. According to Afzal and Zahid (2004), the levels tolerance of mycotoxin in poultry feed is about $28 \mathrm{ppb}$ that is not affect health and performance of boilers. Giambrone et al. (1985) cited by Watts et al. (2003) stated that the maximal level of Aflatoxin in poultry feed was $0.2 \mathrm{mg} / \mathrm{kg}$. The use of mycotoxin detoxification enhance antibody which improves body weight and decreases feed conversion significantly. The toxicity level of aflatoxin in feed was1,2 ppm (Leeson and Summers, 2005).

The nutrition ingredient of expired bread meal was: crude protein $12.63 \%$; crude fibre $0.13 \%$; fat $4.63 \%$; ash $4.19 \%$ and BETN $78.42 \%$. While corn contained crude protein $7.4 \%$; crude fibre $4.1 \%$ and fat $4.1 \%$. The estimation of energy metabolic of expired bread is $3587 \mathrm{kcal} /$ $\mathrm{kg}$ and those of corn is $3350 \mathrm{kcal} / \mathrm{kg}$. Based on the similarity of nutrient content in the expired bread meal and corn, therefore the research was done to investigate the use of expired bread meal to substitute corn in broiler feed in order to obtain optimum broiler performance. This is considering that the expired bread contains mycotoxin that is sensitive to poultry.

\section{MATERIALS AND METHODS}

The study used 100 male day old chick (DOC) broiler, strains Ross 308 and trademarked as $707 \mathrm{CP}$, with the average body weight of $37 \pm$ 0.21 g. Twenty plots litter cages and the equipments were used for the maintenance of these chicks. Five day old chicks were used in each experimental unit. The treatments were the substitution of corn with expired bread meal those were: $0 \%$ (T0), 10\% (T1), 20\% (T2), 30\% (T3) and $40 \%$ (T4). The composition of the diet and nutritional content of diet can be seen in Table 1 .

The study was started by making the expired bread meal and rearing the day old chick for 2 weeks. The expired bread meal was made by drying the expired bread for 3 days, and then grinded. At this time, the chicks were given feed containing $23 \%$ protein and $2900 \mathrm{kcal} / \mathrm{kg}$. The treatments were applied when chickens were 2 to 7 weeks of age. A Completely Randomized Design was used in this study, with 5 treatments and each treatment was repeat 4 times. The variables measured were feed consumption, body weight gain, carcass weight, carcass percentage and feed conversion. Data were analyzed by analysis of variance, and followed by Duncan's Multiple Range Test (Steel and Torrie, 1995).

\section{RESULTS AND DISCUSSION}

The effect of treatments on all variables can be seen in the Table 2 . The substitution of corn by expired bread meal significantly effected ( $P$ $<0.05$ ) on feed consumption and weight gain, but it did not significantly affect on carcass weight, carcass percentage and feed conversion. The substitution of corn with $30 \%$ expired bread meal did not have significant effect on feed consumption and weight gain, but those substitution at $40 \%$ decreased significantly $(\mathrm{P}<0.05)$ on feed consumption and weight gain.

\section{Feed Consumption}

As shown in Table 2, it indicated that the substitution of corn with $40 \%$ expired bread meal had significantly effect on the feed consumption ( $\mathrm{P}<0.05$ ). Feed consumption of $\mathrm{T} 4$ was significantly lower than those of T0, T1, T2 and T3. Feed consumption was affected by energy contain of the feed ( Richards and ProszkowiecWeglarz, 2007) and crude fibre (North and Bell, 1990) The energy and crude fibre contain of the feeds were almost same. The low feed consumption of T4 was probably because of the excess proportion of expired bread meal that caused different flavour. Expired bread meal might be grown by fungi. Mycotoxins were produced by fungi (Santurio, 2000). According to Hattab (1977) cited by Syamsu (2002), storage can cause changes in smell and taste or flavour. Sarastani et al. (2002) reported that long of storage may cause several decreasing of nutrition quality, safety, flavour (taste) and texture, even the smell and taste (Tjandrawati, 2003). The results of the study in accordance with the opinion of North and Bell (1990) that the taste/flavour influences the feed consumption of poultry. The lowest feed consumption of T4 was also caused by mycotoxin. Swammy et al. (2004) found that mycotoxin had a negative effect on feed consumption. Mycotoxin was toxic substance produced by fungi. The research of Watts et al. (2003) and Chowdhury and Smith (2004) showed, that mycotoxins in diet decreased feed consumption and body weight gain significantly but feed convertion was not significantly different. Similarly to the research of Swammy et 
Table 1. Feedstuffs Composition and the Nutrient Content of the Experimental Diet.

\begin{tabular}{lrrrrr}
\hline & \multicolumn{1}{c}{ T0 } & \multicolumn{1}{c}{ T1 } & \multicolumn{1}{c}{ T2 } & \multicolumn{1}{c}{ T3 } & \multicolumn{1}{c}{ T4 } \\
\hline Feed Composition: & & & & & \\
\hline Expired bread meal (\%) & 0.00 & 4.80 & 9.60 & 14.40 & 19.20 \\
Corn (\%) & 48.00 & 43.20 & 38.40 & 33.60 & 28.80 \\
Rice bran (\%) & 13.90 & 13.90 & 13.90 & 13.90 & 13.90 \\
Coconut extract (\%) & 14.00 & 14.00 & 14.00 & 14.00 & 14.00 \\
Soybean extract (\%) & 16.00 & 16.00 & 16.00 & 16.00 & 16.00 \\
Fish meal (\%) & 8.00 & 8.00 & 8.00 & 8.00 & 8.00 \\
Top Mix (\%) & 10.00 & 0.10 & 0.10 & 0.10 & 0.10 \\
\hline Totally & 100.00 & 100.00 & 100.00 & 100.00 & 100.00 \\
\hline Nutrient content: & & & & & \\
\hline Protein (\%) & 16.34 & 16.59 & 16.85 & 17.09 & 17.35 \\
Fat (\%) & 7.18 & 7.21 & 7.23 & 7.25 & 7.28 \\
Crude fibre (\%) & 7.73 & 7.54 & 7.35 & 7.16 & 6.97 \\
EM (kcal / kg) & 3028.82 & 3039.24 & 3.049 .65 & 3060.07 & 3070.48 \\
\hline
\end{tabular}

Table 2. The Effect of Treatments on Broiler Performance

\begin{tabular}{lrrrrr}
\hline Variables & \multicolumn{1}{c}{ TO } & \multicolumn{1}{c}{ T1 } & \multicolumn{1}{c}{ T2 } & T3 & T4 \\
\hline Feed consumption (g) & $1806.32^{\mathrm{a}}$ & $1815.43^{\mathrm{a}}$ & $1807.17^{\mathrm{a}}$ & $1786.47^{\mathrm{a}}$ & $1756.00^{\mathrm{b}}$ \\
Body weight gain (g) & $1194.75^{\mathrm{a}}$ & $1207.00^{\mathrm{a}}$ & $1183.75^{\mathrm{a}}$ & $1167.50^{\mathrm{a}}$ & $1117.50^{\mathrm{b}}$ \\
Carcass weights (g) & $748.62^{\mathrm{a}}$ & $787.00^{\mathrm{a}}$ & $735.75^{\mathrm{a}}$ & $738.12^{\mathrm{a}}$ & $704.62^{\mathrm{a}}$ \\
Carcass percentage (\%) & $60.68^{\mathrm{a}}$ & $63.79^{\mathrm{a}}$ & $61.59^{\mathrm{a}}$ & $63.41^{\mathrm{a}}$ & $62.77^{\mathrm{a}}$ \\
Feed conversion & $1.52^{\mathrm{a}}$ & $1.50^{\mathrm{a}}$ & $1.5^{\mathrm{a}}$ & $1.53^{\mathrm{a}}$ & $1^{\mathrm{a}}$ \\
\hline
\end{tabular}

Different superscript in the same raw indicate statistically differences $(\mathrm{P}<0.05)$.

al. (2004) that reported that broiler weight gain decreased from 21 to 42 days of age when given diet containing mycotoxin.

Feed consumption of $\mathrm{T} 0, \mathrm{~T} 1, \mathrm{~T} 2$ and $\mathrm{T} 3$ were not significantly different, these were caused by the low proportion of expired bread meal. The content of mycotoxin was estimated still bellow the toxic level. The tolerant levels of mycotoxin in the poultry feed was $28 \mathrm{ppb}$ (Afzal and Zahid, 2004) or $0.2 \mathrm{mg} / \mathrm{kg}$ (Giambrone et al., 1985 cited by Watts et al., 2003).

\section{Body Weight Gain}

The more the feed consumption, the higher the body weight gains. The results of this research in accordance with the opinion of Emman and Charles (1989), that feed consumption has an effect in body weight gain. The substitution of corn with $40 \%$ expired bread meal (T4) significantly decreased weight gain. The decrease of weight gain was caused by a taste or flavour and mycotoxin from expired bread meal. Expired feed or feedstuff may cause the growth of fungi that produced mycotoxin. Therefore, the used of expired bread meal will higher mycotoxin content in the feed. According to Ensminger (1980), a high mycotoxin in feed can inhibit animal growth. Watts et al. (2003) reported that mycotoxin in the feed decreased the weight gain of broiler (from 1 to 21 days). The high levels of mycotoxin in feed resulted in the decreasing of serum albumin, total protein, and globulin and blood calcium. The research of Swammy et al. (2004) showed that the increase of mycotoxin also reduced the body weight of chicken broilers age from 21 to 42 days. Girish $e t$ al. (2008) reported that a diet containing mycotoxin decreased turkey's weight gain during grower and developer phases. Mycotoxin can be produced during storage of feedstuff.

The body weight gain of $\mathrm{T} 0, \mathrm{~T} 1, \mathrm{~T} 2$ and $\mathrm{T} 3$ was not significantly different, it may be caused 
by mycotoxin content in T0 - T3 was still in the normal range that did not interfere the growth process. The tolerant mycotoxin levels in poultry feed is $28 \mathrm{ppb}$ (Afzal and Zahid, 2004). In addition, the feed consumption of T1 - T3 was also not significantly different, therefore, the body weight gain was also not significantly different.

\section{Carcass}

Carcass weights and carcass percentages were not significantly different $(\mathrm{P}>0.05)$ in all treatments of corn substituted by expired bread meal 0\% - 40\% (T0 - T4); although the T4 had the lowest feed consumption and body weight gain. These results were due to the bread was made of several materials such as wheat flour, eggs, sugar, margarine, cooking oil and some materials used as the contents of green beans, coconut, chicken meat and beef meat. All of these components are source of protein and amino acids (NRC, 1994). The more used of expired bread meal to substitute corn should gave a better quality of diet. Therefore, although the feed consumption of T4 was the lowest, produced the same carcass weight and carcass percentage. Feed ingredients derived from nuts (leguminoceae) has completely amino acid, especially essential amino acid. Amino acid from nut (leguminoceae) almost equal to animal protein.

Wahyu (1977) stated that animal proteins have more completely amino acid than plant protein. Protein consumptions were relatively the same in each treatment. The function of protein is primarily to build muscle/meat. A carcass is a part of chicken that contains muscle/meat. The proportion of expired bread meal in $\mathrm{T} 4$ was higher than those in T0, T1, T2 and T3, therefore, it may contain more complete amino acid, so although the feed consumption and body weight gain decreased, the weight and percentage of carcass were not significantly different. The research of Quentin et al. (2005) concluded that amino acids affected the production of carcass.

\section{Feed Conversion}

The substitution of corn with expired bread meal 0 - 40\% had not affected feed conversion ratio. In the treatments of $\mathrm{T} 1-\mathrm{T} 3$, the feed consumption and the weight gain were not significantly different, therefore, the feed conversion were relatively the same. In the treatment of $\mathrm{T} 4$, the content of expired bread meal was the highest. Therefore, it might contain the highest mycotoxin that caused reducing feed consumption and body weight gain as Swamy et al., (2002) and Watts et al., (2003) and reported that the addition of mycotoxin on diet reduced feed consumption and body weight gain simultaneously. As a result, the feed conversion was not significantly different. The experiment of Chowdhury et al., (2005) showed that the mycotoxins level $0.8-17.7 \mu \mathrm{g} / \mathrm{g}$ diet not significantly effect on feed efficiency of duck.

\section{CONCLUSION}

The conclusion of the research is the substitution corn with expired bread meal up to $30 \%$ in diet produced the most optimal performance compared to $40 \%$. The substitution corn with expired bread meal $40 \%$ was decreased body weight gain.

\section{REFERENCES}

Afzal, M. and S. Zahid. 2004. Effect of addition of mycotoxin detoxifier in poultry feed containing different levels of afflatoxins on the performance of broiler. AsianAustralasian J. Anim. Sci. 17: 990- 994.

Chowdhury, S.R. and T.K. Smith. 2004. Effect of feeding blends of grains naturally contaminated with fusarium mycotpxins on performance and metabolism of laying hens. Poult. Sci. 83:1849-1856.

Chowdhury, S.R., T.K. Smith, H.J. Boermans, A.E. Sefton, R. Downey and B. Woodward. 2005. Effect of feeding blends of grains naturally contaminated with fusarium mycotoxins on performance, metabolism, hematology and immunocompetence of ducklings. Poult. Sci. 84:1179-1185.

Emmans, G.C. and D.R. Charles. 1989. Climatic Environment and Poultry Feeding in Practice. First Ed. Ancher Press Ltd., Essex, UK.

Ensminger, M. E.,1980. Poultry Science. Second edition. The Interstate Printers \& Publishing, Inc. Danville, Illinois.

Girish, C.K., T.K. Smith, H.J. Boermans and N.A. Karrow. 2008. Effect of Feeding Blend of Grains Naturally with Fusarium Mycotoxins on Performance, Hematology, Metabolism and Immunocompetence of Turkey. Poult. Sci. 87:421-432.

Labier, M. and LB. Eclercq. 1994. Nutrition and Feeding of Poultry. Nottingham University Press. (Translated and edited by J. 
Waseman).

Leeson, S. and J. D. Summers. 2005. Commercial Poultry Nutrition. Third Edition. University Books, Guelph, Ontario, Canada.

NRC 1994. Nutrient Requirement of Poultry. Ninth Edition. National Academy Press, Washington D. C.

North, M. O. and D. D. Bell. 1990. Commercial Chicken Production Manual. Thrid Edition. Van Nostrand Reinhold, New York.

Quentin, M., I. Bouvarel and M. Picard. 2005. Effect of the starter diet, loight intensity and essential amino acids level on growth and carcass composition of broilers. J. App. Poult. Res. 14: 69-76.

Richards, M.P. and M. Proszkowiec-Weglarz. 2007. Mechanisms regulating feed intake, energy expenditure and body weight in poultry. Poult. Sci. 86:1478- 1490.

Sarastani, D. Soewano, T. Soekarto, Tien R. Muchtadi, D. Fardiaz and A. Apriyantono. 2002. Aktivitas antioksidan ekstrak dan fraksi ekstrak biji Atung. Jurnal Teknologi dan Industri Pangan 2:149-156.

Santurio, J.M. 2000. Mycotoxins and mycotoxicosis in Poultry. Rev. Bras. Clenc. Avic. 2: 1-12. doi: 10.1590/5151635X2000000100001

Steel, R. G. dan J. H. Torrie. 1995. Prinsip dan Prosedur Statistika Suatu Pendekatan
Biometrik. Edisi ke-2. PT Gramedia, Jakarta. (Translated by B. Sumantri )

Swamy, H.V.L.N., T.K. Smith, P.F. Cotter, H.J. Boermans and A.E. Sefton. 2002. Effect of feeding blends of grains naturally contaminated with fusarium mycotoxins on production and metabolism in broilers ${ }^{1}$. Poult. Sci. 81: 966 - 975.

Swamy, H.V.L.N., T.K. Smith, N.A. Karrow and H.J. Boermans. 2004. Effect of feeding blends of grains naturally contaminated with fusarium mycotoxins growth and immunological parameters of broiler chicken. Poult. Sci. 83:533- 543.

Syamsu, J.A. 2002. Penyimpanan Pakan Ternak: Tinjauan Proses Kimiawi dan Mikrobiologi. Jurnal Protein Fakultas Peternakan dan Perikanan Universitas Muhammadiyah Malang 19:1331- 1337.

Tjandrawati, M.M. 2003. Analisis Butilhidroksinal (BHA) dalam Minyak Goreng. SIGMA 6(1):17-27.

Wahyu, J. 1997. Ilmu Nutrisi Unggas. Gadjah Mada University Press, Yogyakarta.

Watt, C. M., Y. C. Chen, D. R. Ledoux, J. N. Broomhead A. J. Bermudez and G. E. Rottinghaus. 2003. Effect of mycotoxins and a hydrated Sodium Calcium Aluminisilicate in poultry. Int. J. Poult. Sci. 2(6): 372-378. 